\title{
Mormonism and the Chinese State
}

Becoming an official church in the People's Republic of China?

\section{Pierre Vendassi}

Translator. Will Thornely

\section{CpenEdition}

\section{Journals}

\section{Electronic version}

URL: http://journals.openedition.org/chinaperspectives/6383

DOI: 10.4000/chinaperspectives.6383

ISSN: 1996-4617

\section{Publisher}

Centre d'étude français sur la Chine contemporaine

\section{Printed version}

Date of publication: 1 March 2014

Number of pages: $43-50$

ISSN: 2070-3449

\section{Electronic reference}

Pierre Vendassi, « Mormonism and the Chinese State », China Perspectives [Online], 2014/1 | 2014

Online since 01 January 2017, connection on 28 October 2019. URL : http://journals.openedition.org/ chinaperspectives/6383; DOI : 10.4000/chinaperspectives.6383 


\title{
Mormonism and the Chinese State
}

\author{
Becoming an official church in the People's Republic of China?
}

\author{
PIERRE VENDASSI
}

\begin{abstract}
The Church of Jesus Christ of Latter Day Saints - the mainstream Mormon Church - has been seeking to establish itself in the People's Republic of China since the 1980s. Unlike other religious movements of Christian and foreign origin, which have chosen to go underground, the LDS Church has adopted a strategy of complying with the law and negotiating with the state to obtain official authorisation to conduct its religious activities. The aim of this article is to describe and examine the basis, the form, and certain observable effects of such a strategy, both on an institutional level and in terms of the religious identities that are produced.
\end{abstract}

KEYWORDS: Mormonism, China, the state, inculturation, religious market, regulation, distinction, identity.

$\mathrm{O}$ nly a small amount of research has been carried out on the establishment of Mormonism (moermenjiao 摩爾門教) in the People's Republic of China (PRC), due to the recent nature of this move, its limited demographic scope, and the discretion of the social actors involved. (1) Yet it deserves the attention of observers of religion and of China for several reasons. Firstly, the spread in China of a religion that was born in the United States in the nineteenth century provides an opportunity to observe a particular process of glocalisation, and in this way fuels the debate concerning the spread and local adaptation of a globalised religious order. Secondly, the Church of Jesus Christ of Latter Day Saints (LDS Church; Yesujidu houqi shengtu jiaohui 耶穌基督後期聖徒教會) appears to have a number of characteristics that could be expected to impede its establishment in China, given the religious regulations in force. Indeed, it is a highly bureaucratic, hierarchical, and centralised organisation managed from the United States, and one that advocates the strong allegiance of its members to the institution. (2) In theory, such organisations cannot develop legally on Chinese territory. Thirdly, the strategy adopted by the LDS Church to establish itself in the PRC is based on dialogue with Beijing and the strict observance of religious regulations to obtain official authorisation of its activities. At a time when, despite government repression, (3) other Christian religions are spreading in China outside the legal framework, this appears to be an atypical approach. (4) Using existing scientific, journalistic, and ecclesiastical literature, and interviews, observations, and information gathered on the ground, ${ }^{(5)}$ this article aims to shed light on the situation of the LDS Church in China by examining the foundations, forms, and some of the observable effects of this strategy, in particular in terms of institutional development and the religious identities produced locally.

\section{From missionary church to diplomatic $\operatorname{church}^{(6)}$}

The strategy of the LDS Church needs to be looked at in the light of the history of its relations with China. Soon after the movement became established in the western United States, Mormon leaders sent reconnaissance missions to various parts of the world. As early as 1851, missionaries were sent for short periods of time to Asia, and in 1852, two of them went to
Hong Kong, which was then a British colony. But the Taiping Rebellion (1851-1864) discouraged them from exploring continental China. ${ }^{(7)}$ The unenthusiastic reception given by both locals and colonists to the Mormon message in Hong Kong, compounded by difficulties in adapting to the climate, culture, and language, got the better of their mission there. The missionaries returned to Salt Lake City after less than a year with an unfavourable view of opening a mission in China. ${ }^{(8)}$ Although Protestantism was developing during the same period in China's foreign concessions and beyond, it remained out of bounds to the still fledgling LDS Church. In 1910, on his return from a successful mission to Japan, Alma O. Taylor visited Korea and China in order to once more assess the possibilities of a missionary drive. (9) The report he submitted to LDS Church leaders was once again negative, for the same reasons as before.

A third foray into China was attempted in 1921, when David O. McKay, leader and future president of the LDS Church, undertook a "world tour

1. It is mentioned in a few articles, including: Kim-Kwong Chan, "Religion in China in the Twentyfirst Century: Some Scenarios," Religion, State \& Society, Vol. 33, No. 2, 2005, pp. 87-119; David A. Palmer, "From 'Congregations' to 'Small Group Community Building'," Chinese Sociological Review, Vol. 45, No. 2, 2012, pp. 78-98.

2. Thomas F. O'Dea, "Mormonism and the Avoidance of Sectarian Stagnation: A Study of Church, Sect, and Incipient Nationality," American Journal of Sociology, Vol. 60, No. 3, 1954, pp. 285-293.

3. Daniel Bays, "Chinese Protestant Christianity Today," The China Quarterly, No. 174, 2003, pp. 488504.

4. Other religious organisations, including Bahá'i and Yiguandao, are in talks with the Chinese authorities as part of different strategies and operating modes. See: Sébastien Billioud, "Le rôle de l'éducation dans le projet salvateur du Yiguandao" (The role of education in the Yiguandao salutory project), Extrême-Orient Extrême-Occident, No. 33, 2011, pp. 211-234; David A. Palmer, "From 'Congregations' to 'Small Group Community Building,'" art. cit.

5. In-depth individual interviews conducted with 18 Chinese people who have converted to Mormonism and live in the PRC, in addition to various observations and informal discussions in the context of a broader survey into the workings of the affiliation and conversion of Chinese people to Christian or para-Christian organisations.

6. As the LDS Church is not a state, the term "diplomatic" should not be understood in the strict sense of the term. It refers here rather to the relations between a transnational religious institution and a state, as a form of non-governmental diplomacy comparable to that practised by non-governmental organisations.

7. For a detailed account of this episode, see Lanier R. Britsch, From the East:The History of the Latter-day Saints in Asia, Salt Lake City, UT, Deseret Book Co., 1998, pp. 8-40; Church News, www.ldschurchnews.com/articles/58550/Country-information-China.html (accessed on 20 April 2013).

8. Lanier R. Britsch, From the East, op. cit., p. $36 \mathrm{ff}$.

9. Reid L. Neilson, "Alma O. Taylor's Fact-Finding Mission to China," BYU Studies, Vol. 40, No. 1, 2001, Pp. 176-203. 
of missions" in order to identify new development opportunities for the organisation. Although he made the symbolic gesture of consecrating China to missionary work at this time, ${ }^{(10)}$ the first Mormon mission on Chinese soil would not open until 28 years later, in 1949. (11) As the year of their arrival coincided with the Communist takeover of the mainland, the Mormon emissaries remained confined to Hong Kong and Macao. Then, in 1956, the first Mormon missionaries set foot on the island of Taiwan, and the LDS Church has since then enjoyed stable and moderate growth in these three territories. In 2009, there were 32 Mormon congregations in Hong Kong with 23,223 members, 1,260 believers in Macao, and a total of 91 congregations and 49,054 followers in Taiwan. (12)

Despite this moderate but sustained level of development in the Chinese cultural area, the continent's doors stayed closed to the LDS Church for over a century. At the start of the 1980s, when China was opening up to the world and starting its economic transition, the leaders of the LDS Church, which was growing rapidly on a global scale at the time, tried their luck once more. The customary missionary strategy, based on evangelising populations, gave way to a strategy based on political and legal negotiation with representatives of the Chinese state, apparently relegating evangelisation to the background. This strategy was first implemented in 1979, when a dance troupe from the Mormon Brigham Young University (BYU), the Young Ambassadors, was granted the opportunity to perform in Beijing and other Chinese cities with the support of influential businessmen and politicians. ${ }^{(13)}$ This tour, and the many others that followed, provided an opportunity to forge relations with economic and political players, which led to the establishment of a dialogue between the Mormon and Chinese authorities. Henceforth, discussion and negotiation between representatives of the LDS Church and of the Chinese state was to be the privileged means by which the LDS Church sought to achieve legitimacy in China, while during the same period, Christianity was spreading in various forms over the territory, brought in by zealous evangelists and religious organisations - of both local and foreign origin - who favoured putting in work on the ground over political negotiations. Contacts between Mormon dignitaries and Beijing involved members of the highest grades of the two administrations. Between 1980 and 1996, a number of official Chinese delegations established contact with the LDS Church and its leaders during official visits to the United States, and several senior Mormon leaders visited China in their capacity as religious leaders. ${ }^{(14)}$ The most striking of these visits included those made in 1994 by Li Lanqing, then Vice-Premier of the State Council, to the Polynesian Cultural Center (owned by the LDS Church) in Hawaii, and that made two years later by Gordon B. Hinckley, president of the LDS Church, to the China Folk Culture Villages in Shenzhen. Alongside these informal meetings on the occasion of academic or cultural events, negotiations and discussions took place between senior leaders and lawyers of the LDS Church and high-ranking civil servants responsible for religious affairs. ${ }^{(15)}$ These meetings generated positive reports on the Mormon side concerning a possible expansion into China and, surprisingly, concerning the state of religious freedom in the country. In January 1989, two Mormon leaders returning from China stated:

We have assurance from the highest levels of Chinese government that people are free to practice religious beliefs in China. [...] We were assured that the people in China or Chinese citizens who are abroad are free to join any religious denomination they choose and to practice the tenets of that religion in China without fear of repression.
[... You can be a Latter-day Saint and live in the People's Republic of China, and you won't be isolated from your fellow members of the Church or penalised for your beliefs." (16)

Despite this initial enthusiasm, meetings began to take place with greater discretion after 1996, and announcements made by the LDS Church focused on the fact that it did not have an official presence in China and that it was not sending missionaries there. This discretion proved to be a condition for the continuation of dialogue with the Chinese state.

It is only possible to speculate on the reasons that pushed the Chinese state to embark on and maintain such a dialogue. During a period of economic and social reform brought about by the need for pragmatism, the Chinese authorities doubtless saw an opportunity to test a new form of religious manipulation by benefitting, through cooperation, from the social resources produced by a religious organisation that presented itself as being capable of producing players respectful of the law and actively contributing to social stability and economic prosperity. The risk, meanwhile, was minimal, given the extremely limited size of the Mormon population of China. By agreeing to conduct a dialogue with an American religious organisation, and possibly allowing it margins for manoeuvre, the Chinese state was also providing itself with proof of its own credibility and with counter-arguments that it could point to in the face of criticism and pressure brought to bear by the international community with regard to the observance of human rights and individual freedoms. However, since giving too much visibility to its adoption of a relatively accommodating attitude towards a foreign and heterodox organisation risked stirring up the religious demands of other organisations, Beijing adopted a discrete position and insisted that the LDS Church do the same. ${ }^{(17)}$ This insistence on discretion was stepped up in the 2000s and was scrupulously observed by the LDS Church, because the increase in the number of LDS followers in China preached caution at a time when experiments by the Chinese state in religious matters was giving rise to critical situations. ${ }^{(18)}$

2010 marked another change of direction, when three major announcements were made concerning the situation of Mormonism in China. On 30 August 2010, the LDS Church released a short statement concerning its activities in China:

The First Presidency and other senior leaders at Church headquarters in Salt Lake City have had discussions with a senior official of the

10. The transcription of the words spoken on the occasion of this ritual is available at the following website: www.ldschinese.com/library/dedications/CD.html (accessed on 20 April 2013).

11. Lanier R. Britsch, From the East, op. cit., pp. 227-231.

12. Small congregations form "branches" (fenhui), while the larger ones are known as "parishes" (zhihui). More data is available at Church News, www.ldschurchnews.com/articles/58550/Countryinformation-China.html and Cumorah, www.cumorah.com/index.php?target=main (accessed on 20 April 3013)

13. For an account of the initial meetings: Dallin H. Oaks, "Getting to Know China," BYU Speeches, 1991, http://speeches.byu.edu/?act=viewitem\&id=572 (accessed on 20 April 2013).

14. Church News, www.ldschurchnews.com/articles/58550/Country-information-China.html (accessed on 20 April 2013)

15. It is difficult to obtain accurate information concerning the players involved and the modes of negotiation. At a minimum, they involved agents of the State Administration for Religious Affairs and agents of the National Security Bureau.

16. Statement made by Dallin H. Oaks and Russel M. Nelson, Church News, 28 January 1989, www.ldschurchnews.com/articles/19535/China-Two-apostles-visit-assured-that-religious-freedom-exists-and-people-are-free-to-worship-as-they-choose.html (accessed on 20 April 2013).

17. See Kim-Kwong Chan, "Religion in China in the Twenty-first Century: Some Scenarios," Religion, State \& Society, Vol. 33, No. 2, 2005, pp. 87-119.

18. During this time, Falun Gong, which had previously been tolerated, was violently repressed. 
People's Republic of China from Beijing, and have established a relationship, which we expect will lead to regularising the activities of The Church of Jesus Christ of Latter-day Saints in China. ${ }^{(19)}$

This statement made relations between the LDS Church and Beijing public and, with the approval of Beijing, made the existence of a discussion and formal negotiations between the two entities official. It also allowed the Chinese government to assert its ability to keep an ambitious foreign religious organisation under its control, as part of a renewed political will to bring religious groups of uncertain status back under the rule of law. ${ }^{(20)}$ Then, in December 2012, Russell M. Nelson, a senior leader of the LDS Church and honorary professor at Shandong University, restated the intention of the LDS Church not to send missionaries to China:

One popular rumor in circulation is in regard to missionaries who are called to one area and transferred to open the work in another formerly closed area, such as China [...] Such rumors are absolutely false. [...] Leaders of this Church enter countries new to the Church through the front door. We do not go in through the back door or via the alley. Our relationships are based on honesty, openness, integrity, and complete compliance with local law. (21)

This message, addressed to a Mormon audience, also represented a public re-assertion of the LDS Church's commitment to comply with the rules issued by Beijing. Indeed, two months later, the LDS Church opened a website in Chinese (traditional and simplified) and in English, confirming the existence of Chinese congregations formed with the approval of Beijing since 2004 and restating the limits governing its exercise of religious activity. (22) It is presented as being intended for Chinese people who have converted while abroad and wish to know the conditions under which they can practise their faith on their return to China. It also implicitly expresses Beijing's acceptance of partially publicising (23) the presence of the LDS Church in China. Adopting the negotiation strategy appears to have enabled the LDS Church to acquire a precarious, but no less real, level of recognition there, and although it has no official status, it is authorised to exercise its activity in a limited and strictly controlled manner.

\section{The "red church" strategy?}

The strategy adopted by the LDS Church therefore aims to comply with the rules decreed by Beijing in order to obtain authorisation to practise its religious activity, and ultimately to gain official status in China. Since it is neither prohibited nor fully authorised, the LDS Church is currently positioned in the grey market of religion but is seeking to enter the red market of legal religious organisations. (24) This will involve a significant adjustment and the renunciation of certain normal development methods that are nevertheless anchored in the culture of the organisation, such as systematic evangelisation by full-time volunteer missionaries, encouragement of lay members to openly share their faith, and image building marketing ${ }^{(25)}$ aimed at a wide audience. The leaders of the LDS Church swiftly accepted the need to adapt, as illustrated by this statement made by a senior leader in 1991:

People sometimes ask me about what can be done to "open China." In response, I state my belief that China is already "open" - it is we who are closed. [...] We expect the Orient to be the same as the
West, China to be the same as Canada or Chile. We must open our minds and our hearts to the people of this ancient realm (sic) and this magnificent culture. We must understand their way of thinking, their aspirations, and their impressive accomplishments. We must observe their laws and follow their example of patience. We must deserve to be their friends. (26)

But what this declaration pandering to a certain Chinese nationalism does not say is that a total adaptation of the LDS Church to the laws in force would involve abandoning the direction of its movement on Chinese territory. Indeed, no religious movement managed from abroad can be legally recognised, and at present, China's Mormons would have to affiliate themselves with the existing national religious associations, or more improbably, found a sixth independent national religious association if they wish to enjoy official recognition. If the government were to accept such an eventuality, the LDS Church would be in a situation comparable to that of the Catholic Church in China: (27) its allegiance would no longer be to its international headquarters, but to the Chinese state, which would control the movement from within; it would therefore become schismatic. This will to adapt also does not seem to question the enviable - or less enviable - character of official church status, as the doctrinal, clerical, and material restrictions weighing on organisations that already enjoy this status are pushing many believers towards the grey and black markets of religion.

However, the adoption of this strategy is not without foundation, and rests first and foremost on a gamble taken by LDS leaders, who hope that there will be, in the medium term, a softening of religious regulations and a redefinition of the "red church" that will safeguard the organisation from schism. (28) Such a softening is now more than merely hypothetical.

Three reasons shed light on why a strategy based on such a gamble was adopted. Firstly, the hierarchical and centralised structure of the LDS Church aims to maintain a unified organisation by applying, at a local level, the directives issued in Salt Lake City. Local leaders, though enjoying a certain amount of independence in the management of the congregations they oversee, are required to observe these directives and report to their superiors on a regular basis. The system aims to preserve doctrinal, ritual, and nor-

19. The First Presidency and the Council of the Twelve Apostles form a body made up of the 15 highest-ranking leaders of the organisation. The status and identity of the Chinese senior official were not specified. Mormon News Room, www.mormonnewsroom.org/ldsnewsroom/eng/news-releases-stories/statement-from-the-first-presidency (accessed on 20 April 2013).

20. As recent measures to "eradicate" clandestine churches shows, the state does not simply want the evangelical house churches to disappear, but wants to register them for the purpose of control: www.chinaaid.org/2012/04/chinaaid-special-report-chinese.html (accessed on 20 April 2013).

21. Lds.org, 31 December 2012, www.lds.org/church/news/elder-russell-m-nelson-urges-missionaries-to-refute-rumors?lang=eng (accessed on 20 April 2013).

22. www.mormonsandchina.org (accessed on 20 April 2013).

23. In accordance with Beijing's requirements, the site cannot be visited in China.

24. According to Yang Fenggang, state regulations give rise to three separate religious markets: a market of legal organisations (red), a market of illegal organisations (black) and an intermediate market (grey). See Yang Fenggang, "The Red, Black and Gray Markets of Religion in China," Sociological Quarterly, Vol. 47, No. 1, 2006, pp. 93-122.

25. Eliott Mourier, "L'action sociale et humanitaire de l'Église mormone comme stratégie d"image building': le cas du programme 'mãos que ajudam' au Brésil" (The social and humanitarian action of the Mormon Church as an 'image building' strategy: The case of the 'mãos que ajudam' in Brazil), as part of the symposium "Le mormonisme, de la secte à l'église, de l'église aux sectes" (The evolution of Mormonism from sect to church and from church to sects), Bordeaux, December 2012.

26. Dallin H. Oaks, "Getting to Know China," art. cit.

27. Richard Madsen, "Catholic Revival During the Reform Era," China Quarterly, No. 174, 2003, Pp. $468 \mathrm{ff}$.

28. This matches the third and fourth scenarios concerning the development of religion set out in Kim-Kwong Chan, "Religion in China in the Twenty-first Century," art. cit. 
mative uniformity, regardless of the context in which it is being established, thus promoting and exporting a social and cultural model with its religious content. This means that the religious project and the way in which the LDS Church is organised clash with the conditions in which an underground activity can develop, for two opposing reasons. On the one hand, congregations that are created illegally in China run the risk of finding themselves separated from the main organisation, and therefore becoming schismatic. ${ }^{(29)}$ On the other hand, unlike Protestant house churches, which are able to resist government repression because each cell is independent with regard to the others, any repression that may be carried out against a clandestine LDS branch could potentially threaten all the other branches of the organisation, given the links that unite all the branches.

Secondly, the strategy of the LDS Church rests internationally on the aim of becoming a legally recognised movement wherever it establishes itself, and of promoting the idea that a good Mormon is also a citizen who observes the law. This policy of "coming in through the front door" is based on a doctrine of submission to the law and obedience, which is part of the creed of the LDS Church. ${ }^{(30)}$ In this sense, the independentist fervour of nineteenth century utopian Mormonism has largely given way to an increased willingness to promote the model and image of a socially and politically integrated Mormonism, regardless of the context.

A third reason, which is both pragmatic and historical, supplements the first two. First of all, it concerns the typically American experience of the movement. Starting as a sectarian, utopian, and millenarian movement, the LDS Church gradually "normalised" itself under the effect of socio-political pressures until it was fully integrated into the ordinary religious landscape of the United States. This normalisation doubtless helped create conditions favourable to its development; ${ }^{(31)}$ observing the laws of the United States generally results in a guarantee, in return, of being allowed to exercise religious activity in freedom, owing to a principle of "separation of Church and State" that governs relations between religious and political powers. The same does not apply in China, where regulations aim specifically to limit religious activity rather than to allow it to be exercised freely. However, adapting a strategy of observing the law from the American context to one marked by legal hostility to religion has been proven to pay off in the past. The growth of Mormonism in East Germany is one notable precedent that left a mark on the collective imagination of the movement. The establishment of relationships of trust with local political leaders and the observance of the rules in force meant the LDS Church was allowed to conduct its activities there and to build places of worship with the consent of the authorities during the Cold War and before the fall of the Berlin Wall. (32) Backed by the force of this experience, the leaders of the LDS Church are now seeking to reproduce in China a strategy that has enabled it to find favourable outcomes on a number of occasions when faced with religious restrictions.

\section{Acquiring instrumental legitimacy}

Amidst the demands linked to its structure, doctrine, and historical heritage and those imposed by the religious and political context of China, the LDS Church has been attempting in a variety of ways since 1979 to forge an image considered respectable by the Chinese elites in order to increase its margins of manoeuvre.
The Mormon university, BYU, plays a fundamental role in promoting a positive image of Mormonism through cultural and academic activities. After the Young Ambassadors, other troupes have performed regularly in China since 1979, enjoying perennial if somewhat limited success. The tours made by these groups provide the opportunity for institutional players who belong to the Mormon faith to extend their network of relationships within the Chinese elite. At the beginning of the 1980s, the LDS Church sent English teachers to Chinese universities, seeing this as an opportunity to prove its social utility to the government at a time of globalisation. In 1988, the China Teachers Program was set up in the David M. Kennedy Center for International Studies of BYU. Since 1995, more than 60 English teachers have taken part in this programme each year, in particular teaching in 19 Chinese universities in major centres, including prestigious universities such as Fudan and Jiaotong in Shanghai or Renmin and Tsinghua in Beijing. ${ }^{(33)}$ These teachers are retired volunteering couples from the United States who have academic experience or specific skills. While they are not involved in proselytism, they do help increase the respectability of the LDS Church through their work and through their behaviour within Chinese institutions, and they also promote Mormon culture to the future Chinese elite attending these universities. Indeed, since 1989 more than 1,200 students have been coming into contact each year with Mormon teachers. Even though they may not have been able to form a clear idea of the doctrine or religious practices of the LDS Church, they are, as a result of these encounters, made familiar with Mormon players, who are the messengers of a specific religious culture they have been selected to represent. ${ }^{(34)}$

There are also a number of academic exchange programmes linking LDS Church-affiliated universities with certain Chinese universities. Such exchanges help create links of cooperation with China and the Chinese elite, while also contributing, marginally, to the spread of Mormonism in China: by enabling Chinese citizens to visit the United States, the LDS Church is giving itself the chance to convert Chinese nationals outside their country who could, in the long term, fill its congregations in China.

The LDS Church also uses other instruments of a non-proselytising nature to convince the government of its social usefulness. For example, LDS Charities, a Mormon non-governmental organisation (NGO), has a presence in China through volunteer senior couples whose skills and past positions give them an increased level of legitimacy. It establishes relations with local actors by setting up humanitarian, educational, and social projects in the least developed regions of China. Certain legal NGOs that depend directly on the LDS Church contribute to the dialogue with the authorities by offering their expertise and assistance to the rulers and legal

29. It should be noted that the idea of a schism is, for the LDS Church as for many other religious organisations, a moral, theological, and rational threat. Indeed, schismatic movements represent direct competition that could potentially deprive the mother organisation of some of its resources or, in other words, of its members, and cause the mother organisation to invest additional resources in the regulation of relations, or indeed conflicts, with its schismatic branches.

30. "We believe in being subject to kings, presidents, rulers, and magistrates, in obeying, honoring, and sustaining the law"; citation taken from www.lds.org/scriptures/pgp/a-of-f/1?lang=fra (accessed on 20 April 2013).

31. Thomas O'Dea, "Mormonism and the Avoidance of Sectarian Stagnation," art. cit.

32. Raymond Kuehne, Mormons as Citizens of a Communist State: A Documentary History of the Church of Jesus Christ of Latter-day Saints in East Germany, 1945-1990, Salt Lake City, University of Utah Press, 2010, 235 pp.

33. Church News, www.ldschurchnews.com/articles/58550/Country-information-China.html (accessed on 20 April 2013).

34. The programme's application procedure emphasises the academic and educational abilities of candidates and their ability to embody the values of the organisation, being examples of "moral value, professionalism and integrity." 
players of China in terms of developing ideas to improve the setting up of the rule of law.

Finally, although it appears difficult to accurately grasp their true weight in negotiations taking place between the LDS Church and the Chinese government, it should be noted that certain members of the LDS Church who have left to live in China, as well as certain regional leaders, are knowledgeable and respected businessmen and lawyers who doubtless employ their skills and the relations they foster with economic and political players to serve the ends of the organisation. ${ }^{(35)}$

Initiatives such as these, on which the Mormons base their strategy to spread their movement, demonstrate little originality, at least to a point. Many religious groups, in particular Christian ones, use cultural events, university exchange programmes, the development of NGOs, and even economic activity, to fulfil their undertaking to evangelise. Indeed, using a legal cover under which to carry out religious activities in a concealed manner is a feature that is taken for granted in the grey market of religion. ${ }^{(36)}$ Where the strategy adopted by the LDS possibly differs is therefore in the transparency it demonstrates with regard to its religious activities, and in the will to clearly distinguish these activities from social activities aimed at constructing a positive image and a level of legitimacy in the eyes of the authorities. The work of Mormon NGOs, English teachers, and BYU is completely separated from any direct evangelisation activity, and is carried out independently from local religious congregations, whose social initiatives are far more localised and sporadic, and are the result of individual philanthropic initiatives rather than a strategy sponsored by the transnational organisation. (37) Moreover, the LDS Church shows a certain amount of zeal when it comes to complying with regulations, accepting the control the authorities have over activities carried out in the social as well as the religious sphere. No congregation conducts its activity outside the legal framework, and local leaders regularly meet local representatives of the State Administration for Religious Affairs in order to report on their activities and remind their members of the regulations that need to be followed in order to be allowed to continue to worship. (38)

Rather than deploying its economic, cultural, and human capital on spreading its doctrine and on expanding the movement through the rank and file, the LDS Church uses these resources to obtain institutional legitimacy and the trust of the authorities in charge of religious regulation in the country. This represents another difference in the strategy adopted by the LDS Church in China. Whereas religious groups generally prefer to establish an active underground grassroots presence before considering dialogue with local or national power-holders, the LDS Church favours negotiations with national and then local authorities, with a view to subsequently reaching out to the general population. This strategy initially appears to wholly follow the official conception of religion promoted by the state, which aims to organise associations coordinated on a national scale, in a process that unrolls from the state to the local player. However, such an approach would also seem to go against a certain religious reality that is recognised, though not actually spelled out, by the state itself. Indeed, according to the regulations in force, a religious group can hope to register itself with the authorities if it is able to prove its utility in terms of the regular nature of its meetings, its organisational independence and its financial independence, all of which assumes the existence of a grassroots religious activity, before any steps can be taken towards legal recognition. ${ }^{(39)}$ By favouring its institutional recognition at a national level over its establishment among the population as a whole, Mormonism could be considered, to a certain extent, to be reversing the current political logic when it comes to religion.

\section{Margins for manoeuvre and limitations}

However, the LDS Church has not completely given up spreading its gospel within the Chinese population. At the end of the 1970s, Mormons started visiting China for professional reasons; then in 1986, the first expatriate branches were organised, made up mainly of Americans, first in Beijing and Xi'an, then in Guangzhou, Shanghai, and Tianjin. (40) Today, there are approximately 500 expatriate members spread over four districts (meetings of geographically close congregations) and groups present in around 20 cities. Yet negotiations have also made it possible for the LDS Church to obtain some margins for manoeuvre in spreading the Mormon faith in China within and beyond the boundaries imposed by the state.

It is difficult to obtain accurate data concerning the development of the LDS Church in China, insofar as neither the LDS Church nor the Chinese government communicate on this subject. Yet, very soon after China opened up to the outside world, economic exchanges led to the conversion of Chinese citizens outside the PRC who, on their return to the country, continued to practise their faith, at least on an individual basis. Since 1990, the church has appointed leaders of Chinese origin who are responsible for coordinating and supervising the organisation in China. Although after that date it became possible to organise assemblies, whose very limited size meant they qualified as private activities rather than religious meetings, it was not until after 2000 that the first branches were organised, enjoying generally tacit authorisation to worship. Some branches have temporary, renewable written permission from the national or local authorities to meet in certain premises - rented offices or conference centres - while others have only verbal permission, and the smaller groups meet at the home of one of their members with the tacit consent of the authorities. These permissions also allow the provision of materials (books, manuals, hymn books, etc.) necessary to conduct ordinary religious activities, which include Sunday meetings and daily religious study programmes for adolescents, young unmarried adults, ${ }^{(41)}$ and the whole community.

According to our sources, China now has several thousand practising Mormon believers and congregations in every province. The largest, which are located in economically dynamic cities and provinces that are exposed to international exchanges (Shandong, Beijing, Shanghai, Shenzhen, Xi'an, etc.), have around a hundred active members and are organised into districts along the lines of the standard Mormon organisational model. Others are

35. John Huntsman, US Ambassador to China from 2009 to 2011, was a Mormon missionary in Taiwan. However, he did not hold any hierarchical position in the LDS Church during his term as ambassador. The direct or indirect role he may have been able to play in discussions is unknown.

36. Yang Fenggang, "The Red, Black and Gray Markets of Religion in China," art. cit.

37. In 2011, certain members of a congregation we studied took part, together with a Buddhist association, in charity work, informally and without advertising their faith.

38. It therefore seems that any breach of the rules is the result of the individual initiative of converts, who then run the risk of disapproval or may indeed be reprimanded by their superiors. The interviews carried out and observations made confirm that compliance with the regulations is not merely a statement of good intentions.

39. Chan Kim-Kwong and Eric R. Carlson, Religious Freedom in China: A Research Handbook, Santa Barbara, CA, ISAR, 2005, p. 28.

40. Church News, www.ldschurchnews.com/articles/58550/Country-information-China.html (accessed on 20 April 2013).

41. These two programmes, which are respectively named the "seminary" (shenxue yanjiu suo) and the institute, were put in place in one of the branches that we observed. 
spread over the territory and may have just a handful of converts. ${ }^{(42)}$ The Mormon population of China looks derisory when compared with the total population of the country or with all the Christian or para-Christian movements spreading in China since the 1980s. Yet if the evangelical movements in China are considered not as a whole, but as being formed on the one hand from networks of churches comprising several thousand members, and on the other hand from small independent networks with no more than a few hundred participants, the LDS population becomes proportionally comparable to many of them. Furthermore, the development of the movement may appear to be slow, but it seems constant.

That said, it is nevertheless subject to margins for manoeuvre and limitations. The first limitation concerns the possibility of engaging in proselytising activities, which are necessary to the development of the group. Distributing any religious material or messages outside the space assigned for worship is forbidden, as is encouraging others to adhere to the beliefs and practices of the organisation. This limitation is tempered by several margins for manoeuvre. Firstly, like other Christian churches, the LDS Church trains missionaries to speak Mandarin and gives them the specific mission of targeting Chinese expatriates in a number of cosmopolitan megalopolises in North America, Europe, Asia, and Oceania. Some of the people converted in this way populate the Mormon congregations in China when they return to the country. ${ }^{(43)}$ The result of this kind of recruitment is that Mormon congregations in China consist predominantly of quite young (between 20 and 40 years of age), educated, and economically dynamic individuals. In particular, they include many middle managers working in large or mediumsized international companies, as well as businessmen and business owners. These new Chinese Mormons have relatively high levels of international experience and cultural or economic capital. Secondly, converts are authorised to share their faith with members of their family. Some of the growth of the LDS Church on a local scale is provided by inter-family conversions of this kind, which are common in Chinese Mormonism and in many other religious movements. ${ }^{(44)}$ Thirdly, owing to the religious freedom that the Chinese constitution is supposed to protect, a friend or acquaintance of a convert can, if he asks the convert about his belief or practices, visit the place of worship in order to learn more. He will not be given religious material, but can attend an information meeting, as set out by the rules and agreements reached with the authorities. If he then decides to embrace the Mormon faith, he will need to go abroad to be baptised and register as a legitimate member of the organisation; on his return he will be allowed to play a full part in the religious life of the Mormon community. ${ }^{(45)}$

Another limitation the LDS Church must face concerns relations between its headquarters and its local congregations. The official prohibition of religious contact between foreign Mormons and Chinese Mormons in the PRC, in accordance with religious regulations intended to guard against imperialist threats, prevents any direct contact between foreign Mormon leaders and local congregations. ${ }^{(46)}$ Furthermore, the few branches consisting of foreign expatriates in China are strictly separate from the local branches. Although a few attempts were made to bring them closer together after 2004, with the permission of the authorities, this was brought to an end with a return to segregation that remains in force today. This rule is repeated regularly, both by expatriates and local converts, as is that concerning the prohibition of any kind of proselytism. In order to make sure the link between the local leaders and its management is maintained in these conditions, the LDS Church calls on its members who are citizens of the PRC living abroad to monitor the development of its local branches. Moreover, the Internet makes it possible for local members to overcome restrictions relating to the control imposed on the distribution of religious material, because many of the LDS Church's resources are available online in Mandarin.

The third limitation concerns the process of integrating converts into a local congregation. A certain number of Chinese members who have converted abroad break away from the LDS Church between their baptism abroad and their return to China due to the limited size of the Mormon population in China and the difficulty of meeting co-religionists who are geographically close. But it could be speculated that those who do find their way to local congregations after returning to China are all the more likely to form an active core that carries the local religious dynamic forward. Moreover, because Beijing has prohibited baptisms on the territory, locally converted members have no option but to go to Hong Kong in order to become full members of the LDS Church and join the community. They usually organise a short stay in order to be baptised before returning to their city of origin. The investment that this journey can represent, in terms of time and money, could help reduce the recurrent phenomena of baptism followed by immediate disaffiliation that many churches experience, because it prompts potential recruits to consider their choices more carefully than might be the case if the opportunity of a swift and inexpensive baptism were open to them. ${ }^{(47)}$ This could favour the creation of a hard core of members with a strong attachment who are invested in the community. According to our sources, the level of retention of converts after baptism could range from 50 to $70 \%$, whereas it is generally lower in the rest of the world.

\section{The Mormon distinction: Some hypotheses}

Aside from the legal problem posed by the situation of the LDS Church, research into the limitations and margins of manoeuvre revealed that the restrictions imposed on the Church promote the development of an educated and economically active Mormon population that is equipped with international experience and is receptive to the cultural content of Mormonism, capable of taking responsibility for the movement at a local level and encouraged to do so. Broadly speaking, it is not unlike the new generation of city-dwelling Chinese Protestants. The situation brings together the elements needed for swift and successful inculturation. The major question that remains is to what extent the conditions in which the LDS Church is spreading in China and the specific nature of the strategy used influence the future of converts in terms of differentiating them from (or confusing

42. It is difficult to give estimations of the Chinese LDS population, given the lack of communication from the Church and state. In 1991, Dallin H. Oaks, leader of the LDS, stated: "About 10,000 of our members were born in the People's Republic of China, and many still live in that country"; Dallin H. Oaks, Church News, 28 January 1989, art. cit. In 2008, Melvin R. Ballard, another LDS leader, stated: "We now have [in the PRC] some 20 small branches of Chinese members that are authorized to meet"; https://newsroom.byuh.edu/sites/newsroom.byuh.edu/files/u1/BYUH_foundation_documents/Ballard_MRussell_2008_re.pdf (accessed on 15 September 2013). It is possible that the number of branches has increased since then, and it certainly does not take into account many small assemblies that meet privately throughout the country.

43. Fourteen of the 18 people interviewed for our survey were converted while living abroad (Australia, Singapore, United Kingdom, France, the United States, Japan, etc.). It was not possible to obtain any statistical data concerning the scale of these conversions.

44. We met several people who had been converted in this way, including one interviewee. This scenario appears to be an important lever for growth.

45. Three of the people interviewed went to Hong Kong to be baptised before joining their local congregation.

46. Kim-Kwong Chan and Eric R. Carlson, Religious Freedom in China, op. cit.

47. See Carter Charles, "The Mormons and numbers: Statistics and conversion in the Church of Jesus Christ of Latter Day Saints," Cahiers de l'Institut Religioscope, June 2011, No. 6, www.religion.info/ pdf/2011_06_Charles.pdf (accessed on 20 April 2013). 
them with) the rest of Protestant Christianity in China and the rest of transnational Mormonism. Although the extent of the research we carried out does not enable us to give a categorical answer, it does give rise to the following hypotheses that future research will need to verify.

In the light of the interviews that we conducted, it became clear that the above-mentioned strategy of observing the rules could promote a self-sustaining stigmatisation mechanism giving rise, to a certain degree, to an innovation in terms of sense of identity. No doubt due to the fact that Mormonism only recently established itself in China, it is less subject to specific criticism and social condemnation there than in other countries. Distinctive Mormon practices such as the prohibition of alcohol and tobacco consumption, observing a day of rest on Sunday, and customs characterised by moral conservatism, do not set it significantly apart on the Chinese religious scene. Many evangelical churches share similar distinctive practices, and dietary restrictions are a common feature of other established traditions (vegetarianism for practising Buddhists, non-consumption of pork or alcohol for Muslims, the historical ban on eating beef, etc.). The diverse evangelical congregation, in particular, despite the fact that it is developing illegally, produces believers who emphasise their Christian identity and claim a strong social distinction. Our observations, which are based on followers attending various evangelical house churches, demonstrate a strong affirmation of faith ranging from wearing visible religious symbols to organising "evangelisation" concerts, not to mention organising office prayer meetings in non-Christian companies.

The LDS Church appears to nurture this same social distinction on an international scale, sending recognisable missionaries around the world, financing advertising campaigns intended to enhance the image of the movement and its members, and building its speeches around the assertion that it makes a positive difference. Yet one thing that became clear from the interviews we conducted with practising LDS Church converts was a tendency to limit the visibility of their identity markers. Their accounts concerning the practice of concealing or toning down religious markers revealed such behaviour to be all the more pronounced when the marker in question was specific to our Mormon sample. A 30-year-old doctor who had converted to Mormonism during a period of study abroad described this phenomenon as follows:

I do not drink alcohol, tea, or coffee, unlike the people with whom I work. Sometimes they ask me why, and I tell them that it's for religious reasons, but I do not say any more than that, because it is a very sensitive subject.

C., a 29-year-old graduate from a European university receiving training in an international company, shares the same point of view and the same attitude:

I have not told anyone at work that I am a Mormon, because I'm a bit afraid to do so. I don't want people to start asking questions or the girls in the department to start spreading rumours (...) I want to behave like a good person, a fair person, and be a good worker. Then, people will see me as a good person and one day, when they find out I'm a Mormon, they'll say: 'He's a Mormon, you know. And he is not a bad person.'

Others choose to portray themselves as Christians when responding to the questions asked by those around them, thus adopting an identity marker that is both more widespread and more prestigious. The wish to limit the visibility of their Mormon identity is illustrated, in particular, in a position repeated in several interviews concerning marriage choices. Although the LDS religion advocates religious homogamy - the "sealing" or "celestial marriage" (gaoji guodu de hunyin 高級國度的婚姻), forming the highest ritual to attain salvation, is only open to couples who are legitimately married and share their Mormon faith - some unmarried converts tend to minimise the importance of this point in their answers and strategies. For example, one convert stated the following with regard to his non-Mormon fiancée:

Marrying a member is good because it's easy, and you can be sealed and have an eternal family (...). But L. is a truly good person. She is like a traditional sister, like a Mormon sister. She respects her family and loves family life, she respects her elders and looks after her parents, and she does not have worldly concerns, so she is a really good girl, which is important. So I think that although she is not a Mormon, she is a wonderful sister.

Another convert, who has spent time as a missionary for the LDS Church, also accepts the possibility of marrying a non-convert:

It's better if he's a member, but there are not many brothers, and there are still many people that I could meet and get to know; people who also need... need our help. So it would definitely need to be someone who can accept the change in me. After that, God has his ways.

If confirmed, this minimisation of Mormon identity markers, which finds expression even in the marriage strategies of some converts, could be attributed to two connected factors. Firstly, it is possible that the religious limitations in place distort the mechanisms that socialise members towards the models advocated as standard by the LDS Church. As touched upon in the extract above, the restricted size of Mormon communities most certainly limits the total fulfilment of the religious project on both the individual and community levels. Secondly, it seems that the enthusiasm of the Mormon authorities to comply with the laws of the country gives rise among converts to the idea that their religious identity is an identity that presents problems, whereas this element is not present in the statements of believers affiliated to clandestine evangelical movements that do not foster direct relations with the authorities. The Mormons we interviewed made numerous comments concerning the political and social risk that could result if they made too much of a display of their religious identity, and concerning the strangeness of their situation. One young convert described the following situation:

They have installed surveillance cameras [at the church]... That gives you a strange feeling. [...] Because there were more than 50 of us, they were watching us in case something a bit questionable happened.

Yet they all accept the position of the leaders concerning the strategy that needs to be followed, even when describing the difficulty arising from this situation:

If I gave a Book of Mormon [to my girlfriend] that would be frowned upon because it is against the law in China. You can't do that. [...] I 
think the Church is taking the right course of action, because... if you tell people that you're a Mormon, they will think that it's an American church... so you need to be careful.

What makes this statement all the more interesting is the fact that other Christians in China generally see the Western origin of their religion to be a positive argument. ${ }^{(48)}$ The stigmatisation in this case appears rather to be maintained internally, as a result of what could be described as the "red church" paradox: a religious institution, wishing to be recognised by political authorities whose aim is to control and limit religious life, must comply with laws and regulations designed to counter its development and its very nature.

\section{Conclusion: The outlook for Mormonism in China}

The strategy developed by the LDS Church in a context of religious restriction contributes, in certain ways, to the creation of a hard core of skilled, engaged, and autonomous Mormons. The constraints imposed by the state and the willingness of the LDS Church to bend to these constraints appears to be producing, when all is said and done, a slow rate of growth that could also help it take root at a local level. Although negotiations aimed at winning legal legitimacy have enabled the LDS Church to obtain a few margins for manoeuvre, at the time of writing it has still not achieved any more than a precarious semblance of recognition, and does not enjoy any kind of official status. Moreover, the LDS Church also appears to be just as well equipped as many similar new religious movements to forge a place for itself in a Chinese market that is favourable to Western religions, especially because the Mormon social model is similar to that of the "Boss Christians," (49) combining traditional patriarchal values, individual recognition, and the search for economic prosperity. Yet the inculturation process resulting from observing the rules of the red market of religion could also have effects on the production of a specific Chinese Mormon identity. Carrying out further research with Mormon players, with a view to making intra-religious comparisons (in order to compare Chinese Mormonism with other local Mormonist movements) and inter-religious comparisons (in order to compare the development of Mormonism with the development of other groups in China) will help better understand these effects.

\section{Translated by par Will Thornely.}

I Pierre Vendassi is a PhD candidate in sociology at the Centre Émile Durkheim, Université de Bordeaux, and is the co-founder of the Institut Français de Recherche sur le mormonisme (French institute for research on Mormonism).

Département de Sociologie, Université de Bordeaux, 3 ter, place de la Victoire, 33400 Bordeaux, France (pierrevendassi@yahoo.fr). 